\title{
ПЕДАГОГИЧЕСКИЙ МЕНЕДЖМЕНТ: ВОЗДЕЙСТВИЕ ИЛИ ВЗАИМОДЕЙСТВИЕ?
}

\author{
E. С. Харченко
}

Московский гуманитарный университет

Аннотация: Управление педагогическим процессом заключается в оптимизации, целевой ориентации и его активизации управляющим. Рассматриваемое управление основывается на взаимодействии между педагогами, обучающимися. Одновременно идёт управление деятельностью педагогического состава.

ключевые слова: педагогический менеджмент; управление; воздействие; взаимодействие; рефлексивное управление

\section{PEDAGOGICAL MANAGEMENT: IMPACT OR INTERACTION?}

\author{
E. S. Kharchenko \\ Moscow University for the Humanities
}

Аннотация: The management of the teaching process is optimization, targeting and its activation by the manager. The management in question is based on the interaction between teachers and students. At the same time, the management of the teaching staff takes place.

Ключевые слова: pedagogical management; management; impact; interaction; reflexive management

Под менеджментом понимают некую активность, управление. Процесс управления подразумевает наличие субъекта и объекта управления. Соответственно, задача педагогического менеджмента в образовании - повышение эффективности и совершенствование образовательного процесса. Внутришкольное управление - сознательное целенаправленное взаимодействие участников педагогического процесса.

В отечественной практике сформировались различные подходы к понятию «внутришкольное управление». Некоторые из их исходили из того, что управление образовательным процессом - целенаправленное организованное воздействие на составляющие самого процесса и их связей.

Так Г. Г. Габдуллин характеризует школьное управление как воздействие на школьный коллектив, не только организационно-педагогические, а также целенаправленное, системное и плавное. Воздействие это основы- 
вается на изучении закономерностей образовательного процесса и развития коллективов, цель которого обеспечения более качественной учебно-воспитательной работы и воспитания учащихся (Габдуллин, 1985: 9).

Понятие «управление» относится к числу общих понятий и охватывает не только социальные сферу, а также технические и биологические системы. Значит, само по себе управление - это процесс воздействия на функционирование коллектива в учреждении с целью исполнения заданных программ, соблюдения порядка, сохранения единства организации, и как следствие вступления учреждения на следующие этапы развития с сохранением, имеющихся в ней правил и распорядка.

Школа - социальная ячейка общества, следовательно, и управление школой социальное. Социальному управлению присуще целенаправленное внешнее воздействие на управляемый объект.

В любой деятельности школы есть управление: управление познавательной деятельностью учеников (обучение), управление процессом становления личности (воспитание), управление коллективами педагогов и учеников, регулирование отношений между педагогами и родителями необходимы для успешной деятельности всей школы. В процессе общения людей не исключено внушение, влияние лидера и неосознанное подчинение, привычки и групповое мнение и ценности, что не санкционируется управляющими органами и является саморегулированием. Таким образом, школа является самоуправляемой социальной системой.

Под системой понимается совокупность элементов, имеющих между собой устойчивые связи и образующих целостное единство. Как любая социальная система, школа имеет управляющую и управляемую подсистемы. Управляемая подсистема состоит из взаимосвязанных между собой: педагогического, ученического, учебно-вспомогательного и обслуживающего персонала. Управляющая подсистема - совокупность органов управления, состав изменяется в зависимости от уровня управления школой.

Особенность управления школой заключается в том, что учитель и ученик являются не только объектами управления учебно-воспитательного управления, а также и субъектами в контексте самообразования и самовоспитания. Таким образом, управленческое воздействие направлено на решение таких задач, как формирование у педагогического и ученического коллективов социально-психологических состояний, создания творческого настроя, повышения мастерства и уровня работы.

Ю. А. Конаржевский и В. С. Байманковский определяют управление как воздействие руководителя на учебно-воспитательный процесс через воздействие на коллектив педагогических работников. Соответственно, и само воздействие имеет целенаправленный характер, цель которого - до- 
Научные труды Московского гуманитарного университета 2018 № 4

стижение коллективом желательного результата (Конаржевский, Байманковский, 1972: 7). В своём определении они отталкиваются от того, что процесс управления рассматривается как упорядочивание системы, согласно В. Г. Афанасьеву (Афанасьев, 1968: 24).

Управленческая деятельность школой, в том числе состоит из подбора и расстановки сотрудников на местах, определения их прав, обязанностей, ответственности; обучения педагогического коллектива; выполнения распорядительных функций.

По сути, управление - это разработка разумной концепции. Таким образом, управление в образовании - это обдуманное воздействие через учителей на учебно-воспитательный процесс, цель которого получение улучшенных показателей обучения и воспитания.

Школа является общественной системой и управление ей - в первую очередь руководство людьми, сознательное регулирование и организация отношений, происходящих в ней.

Похожее определение школой даёт и М. М. Поташник, указывая на «целеустремлённую деятельность коллективных и индивидуальных субъектов, направленную на обеспечение оптимального развития школы и её оптимального развития» (Поташник, 1991: 30).

М. Г. Захаров подходит к управлению с позиции директора, характеризуя управленческую деятельность как воздействие со стороны руководителя на учебно-воспитательный процесс с целью исполнения поставленных задача. Директор эффективно выполняет свои функции управления, если владеет показателями фактического состояния, при этом имеет знания о том какие они должны быть, чтобы сравнить их и скорректировать педагогический процесс. На основе знаний, полученных из таких источников, как классные журналы, общение с учениками и педагогами, посещение уроков, директор школы принимает решения (Захаров, 1971: 84).

В связи с тем, что в образовательном процессе чаще стали ориентироваться на личности (как педагогов, так и учеников), требуется переосмысление основ внутришкольного управления. Идеи сотрудничества, взаимодействия и рефлексивного управления сменяют философию воздействия.

Т. М. Давыденко выводит определение «рефлексивное управление», которое определяет как «полисубъектное диалогическое взаимодействие» (Давыденко, 1995: 87). В данном взаимодействии обратная связь реализовывается как рефлексивные действия. Цель её состоит в обеспечении саморазвития учреждения.

Термин «рефлексивное управление» появился в психолого-педагогических исследованиях и рассматривался как неотъемлемая характеристика любого межличностного взаимодействия. 
В настоящее время личностно-ориентированный подход является основополагающим в управлении школой. Согласно процессному подходу, управление школой - это процесс, который состоит из комплекса постоянных взаимосвязанных действий.

Исходя из того, что сущность управления заключается в целенаправленном влиянии субъекта управления на объект управления в целях реализации поставленных задач и их взаимодействии, М. И. Кондаков представляет управление как специализированную социально-педагогическую систему, которая направлена на совершенствование учебно-воспитательного процесса, согласно требованиям научно-технического и социального прогресса (Кондаков, 1982: 22).

Между тем, управление - это специфический вид труда, которому присущи творческая активность и способность применять имеющиеся знания.

А. А. Орлов под управлением понимает воздействие не только на отдельные элементы, но и на многогранный организм, цель которого оптимизация учебно-воспитательного процесса (Захаров, 1971: 84).

Особенности управления школы, учебно-воспитательной деятельности, многогранность задач определяют специфику внутришкольного управления.

Управление школой должно основываться на знаниях, учитывая социально-психологические закономерности становления и развития личности и коллектива в целом. Учителя и ученики являются активными участниками педагогического процесса и имеют определённое влияние на его деятельность и результата. Управление в своей деятельности имеет многоуровневые цели, начиная от общей цели воспитания и обучения в общем, до определённой личности учащегося.

Управление обеспечивает целенаправленность и единство деятельности всех подразделений школы и выполняет функции, обусловленные движением всего организма школы.

В соответствии с особенностями протекания учебно-воспитательного процесса управление должно рационально организовать его во времени и пространстве, чтобы он протекал равномерно, не снижая работоспособности учителей и учащихся, а также способствовал укреплению их здоровья.

П. И. Третьяков характеризует управление как - «целенаправленная деятельность субъектов управления различного уровня, обеспечивающая оптимальное функционирование и развитие управляемой системы (субъекта), перевод её на новый, качественно более высокий уровень по фактическому достижению цели с помощью необходимых оптимальных педагогических условий, способов, средств и воздействий» (Третьяков, 1991: 55).

Управленческая деятельность - это деятельность по прогнозированию, 
Научные труды Московского гуманитарного университета 2018 № 4

планированию, принятию решений, а также контроль и регулирование.

Управление, цель которого достижение планируемого результата. В условиях управления по результатам руководитель обязан хорошо владеть ситуацией и быть проводником новизны. Также управление можно трактовать как содействие и поддержка исполнителя в выполнении поставленных задач.

Коллектив авторов в соавторстве с Т. И. Шамовой настаивают, что перевод внутришкольного управления необходим на научные основы, что возможно только условия действий руководителя в своей практической деятельности, опираясь на общие принципы управления. «Гуманизация предполагает переход от подчинения и господства к сотрудничеству и партнёрству, отказ от представлений будто бы лишь школа знает что нужно ученику» (Шамова и др., 1991: 8).

Гуманизировать отношения - означает первостепенно ставить личность ребёнка, направлять всю деятельность на её развитие, основательно изменить педагогический процесс, в соответствии с интересами ребёнка потребностями его творческой самореализации. В данном контексте предполагается разработка и использование системы стимулов и мотиваций деятельности ученика, согласованной с современными требованиями и задачами развития.

Педагогическая сущность управления школой заключается в том, чтобы всё время видеть ребёнка. Ребёнок и его интересы должны быть на первом месте в любом управленческом решении, иначе оно теряет всякий смысл. «Педагогический аспект управления заключается в том, чтобы формировать у учителя умение всегда и во всех обстоятельствах видеть ребёнка, учитывать, как педагогический процесс влияет на ученика, на класс, на отношения учителя с детьми. Нужно научиться понимать, что ребёнок человек, а не просто ученик» (там же: 31 ).

Подтверждая данные выводы, В. П. Симонов предлагает понятие «педагогический менеджмент». Исследователь характеризует педагогический менеджмент как совокупность методов, форм, принципов, приёмов управления, используемых с целью увеличения их результативности и дальнейшего успешного развития. Он рассматривает деятельность руководителей образовательных учреждений с точки зрения педагогического менеджмента, с которой эта деятельность «представляется как непрерывная цепь разрешения постоянных противоречий между формализмом и творчеством в каждом управленческом акте, в каждом управленческом воздействии на подчинённых (учащихся)» (Симонов, 1999: 4).

Управление педагогической деятельностью - вид общественного управления, некая деятельность, направленная на развитие и успешное функционирование образовательного учреждения. В связи с тем, что по ос- 
новному своему содержанию деятельность всех субъектов образования управление, то и по своей сути, управление - гуманитарное, благоприятные условия для совместной деятельности участников образовательного процесса могут быть созданы при условии конструктивных отношений в коллективе. Понятие менеджмента привносит в управление образованием ориентацию на личность, его интересы и потребности, также взаимодействие управляемой и управляющей систем. Таким образом, в настоящее время управление рассматривается как воздействие и взаимодействие всех участников учебно-воспитательного процесса. В основе управления педагогическими процессами - личность.

\section{СПИСОК ЛИТЕРАТУРЫ}

Афанасьев, В. Г. (1968) Научное управление обществом. М. : Изд-во политической литературы. 207 с.

Габдуллин, Г. Г. (1985) Организационно-педагогические основы управления общеобразовательной школой : учебное пособие. Казань : КГПИ. 106 с.

Конаржевский, Ю. А., Баймаковский, В. С. (1972) Пути совершенствования управления школой. Челябинск : Юж.-Урал. кн. изд-во. 116 с.

Поташник, М. М. (1991) Оптимизация управления школой. М. : Знание. 61 с.

Захаров, М. Г. (1971) Организация труда директора школы. М. : Просвещение. $176 \mathrm{c}$.

Давыденко, Т. М. (1995) Рефлексивное управление школой: теория и практика. Белгород : БГПУ, 250 с.

Кондаков, М. И. (1982) Теоретические основы школоведения. М. : Педагогика. 191 с.

Орлов, А. А. (1982) Научные основы управления общеобразовательной школой. М. : МОПИ. 102 с.

Третьяков, П. И. (1991) Управление общеобразовательной школой в крупном городе. М. : Педагогика, 187 с.

Шамова, Т. И., Конаржевский, Ю. А., Нефедова, К. А., Третьяков, П. И. (1991) Внутришкольное управление: вопросы теории и практики. М. : Педагогика. 192 с.

Симонов, В. П. (1999) Педагогический менеджмент: 50 ноу-хау в управлении педагогическими системами. учеб. пособие. 3-е изд., испр. и доп. М. : Пед. о-во России. 426 с.

Дата поступления: 15.08.2018 2.

Харченко Елизавета Сергеевна- студентка магистратуры кафедры педагогики и психологии высшей школы Московского гуманитарного уни- 
верситета. Адрес: 111395, Россия, г. Москва, ул. Юности, д. 5 . Тел.: +7 (499) 374-74-59. Эл. адрес: Ellizabetta5917@mail.ru. Научный руководитель д. п. н., проф. В. А. Ситаров.

Kharchenko Elizaveta Sergeevna, Graduate Student, Department of Pedagogy and Psychology of Higher School, Moscow University for the Humanities. Postal address: 5, Yunosti St., Moscow, Russian Federation, 111395. Tel.: +7 (499) 374-74-59. E-mail: Ellizabetta5917@mail.ru

\section{Для цитирования:}

Харченко Е. С. Педагогический менеджмент: воздействие или взаимодействие? [Электронный ресурс] // Научные труды Московского гуманитарного университета. 2018. № 4. URL: http://journals.mosgu.ru/trudy/article/ view/807 (дата обращения: дд.мм.гг.). DOI: 10.17805/trudy.2018.4.3 